\title{
$\overline{\overline{\text { 究 }}}$ \\ 摩耗試験における形状効果と寸法効果
}

\author{
水 野 万亀 雄* \\ Effects of Shape and Size on Wear \\ Makio Mizuno
}

When a rider slides on virgin surfaces without lubrication, wear of the metals is affected by the shape and size of the test pieces. In this paper, the mechanism of wear, caused by movement of the wear particles is discussed.

It is found that some wear particles, transfered from the test piece to the virgin surface come back again to the original surface and there is an equilibrium state in which the mass of the back transfered particles is equal to the wear particles, transfered from the original surface. This study shows that metal wear $W$ is expressed by the following equation.

$$
\begin{gathered}
W=h_{o} p L_{o} \iint e^{-k_{1} x d x d y} \\
\text { where } \\
p: \text { constant pressure } \\
L_{o}: \text { sliding distance } \\
x: \text { length of test piece } \\
y: \text { width of test piece } \\
h_{o}: \text { transfer constant } \\
k_{1}: \text { back transfer constant }
\end{gathered}
$$

\section{1. まえがき}

摩耗現象は作用因子を数多く含むため複雑な形をと り，その本質はなかなか見きわめ難い。それ的立との解 析はまず単純な条件より始め, 順次汇複雑な実用状態の 条件に拉よぶように，つぎの段階を踏んで功くのが妥当 と思方礼る。

1) 繰り返しのない場合, 非潤滑面と扮汁る解析

2) 繰り返しのない場合, 境界潤滑面に招ける解析

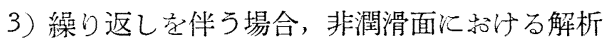

4) 繰り返しを伴う場合, 境界潤滑面汇扮忛る解析 前報》では第 1 段階として繰り返しのない場合つ非潤 滑面汇少计る摩耗と摩擦の関係を論じ, 第 2 報2)では第 2 段階として繰り返しのない場合の境界潤滑面飞括ける 摩耗と摩擦の関係を論じた。それらの報告のなかで試料 の面積効果についてふれたが，本報はとの詳細を試料の 形状と寸法の効果としてまとめた。

この報告擵耗粉の転移 (transfer) 拉よびその1部 が再転移 (back transfer) することを確認した上でそ

* 理化学研究所 正会員
の挙動をとり入れ，繰り返しのない，いわゆる処女面と: ついて解析した。またこの解析はつぎの第 3 段階である 繰り返しを伴うところの初期摩耗現象の説明にも使用で きとうである。

\section{2. 理論的考察}

第 1 報1)，第 2 報2)の繰り返しのない摩耗試験では摩: 耗量が見掛けの荷重飞比例した。しかしこれは限定され。 た実験籁囲内で認められたのであつて，常と成立すると は断言できない。なぜならば荷重が見掛けの接触圧力と 面積の積としてあらわされる以上, 当然との扮の扔のが. 摩耗量と比例しなければならないからである。

接触圧力について $\mathrm{Holm}^{3}$ )

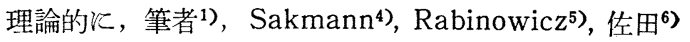
などは摩耗実験から摩耗量は接触圧力に比例すると発表: している。

接触面積と摩耗軖の関係はこれまで比例するといわれ てきたが，常にこの関係を保ち得るか性疑問であり，形 状の効果も含めて考察を持こなととにする。考察を進 めるために、はじめにつぎの仮定をおく。 
伋定 1) 摩耗粉は酸化しない。

硬い金属表面上軟らかな金属試料がすべると，この 試料藦耗して摩耗粉を硬い金属表面に残す。この転移 した摩耗粉は接触面に持ける凝着部の破壊によつて生じ たものであり，摩耗粉が生成した瞬間はすくなくともと の表面は污れていない。この摩耗粉甠表面の突起付近に 凝着するので, 試料表面の突起とらたたび衝突するチャ ンスがあり，そこに酸素が存在すれば衝突数に応じた摩 擦熱によつて酸化されよう。しかしながら繰り返しのな い場合注衝笑寸るチャンスが少ないから，摩耗粉は酸化 されにくい。

仮定 2) 摩耗粉はトラックから飛び散らない。

繰り返しのない摩耗では転移した摩耗粉は相手金属面

飞凝着しており, 簡単に脱落しない。

仮定 3) 摩擦距離低ライダの長さに比べ十分長い。

摩擦距離が微小の上きは摩耗粉の転移のみが行なわ れ, 再転移が叔こらない。それゆ克，そのときの摩耗率 (摩耗量/摩擦距離) は摩擦距離が十分長いときに比較し て大きな值をとる。これから述べようとする考察は摩耗 粉の再転移を主点としているので, 摩擦距離に対してラ イダの長さが無視できる条件が望ましい。

仮定 4) 再転移量恃夫れまでの摩耗量に 1 次比例す る。

転移した摩耗粉の量が多ければライダに再転移する量 も多い之考光, その量忹軑摩耗量すなわちそれまでに すべらせた摩耗量に $n$ 次比例すると仮定するのが一般的 である。しかしながら1次比例すると仮定したところ害 験とよく一致したので採用した。

いま図 1 のような長さ $x$, 幅 $d y$ の角柱のライダに

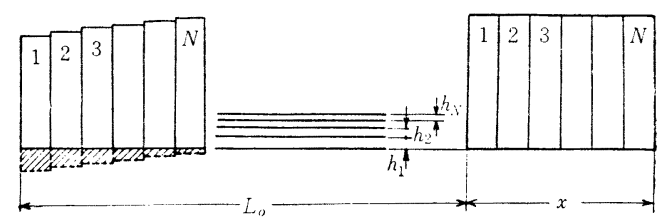

図 1 摩 耗模 型

接触圧力 $p$ を加え， $L_{0}$ だけ前方にすべらせたときの摩 耗量を考えてみる。この摩耗量はライダを長手方向に $N$ 等分し，分割したライダを順々にすべらせることによつ て, それぞれの摩耗量を求めればその総和に相当する。

まず分割したところの初めのライダをすべらせ，摩耗 深さ $h_{1}$ (単位圧力, 単位摩擦距離あたり) が測定され たとするならば, その摩耗量 $d W_{1}$ はつぎの式から求め られる。

$$
d W_{1}=h_{1} p L_{o} d x d y
$$

つぎに 2 番目のライダをすべらせるわけであるが，こ の場合は初めのライダによつて生じた転移摩耗粉の上を すべらせることになり，ライダは摩耗すると同時にまえ に転移していた摩耗粉の1部がライダ表面に再転移もす る。それゆえ2番目のライダの摩耗量 $d W_{2}$ は

$$
d W_{2}=h_{2} p L_{o} d x d y
$$

同样にして, $N$ 番目のライダの摩耗量 $d W_{N}$ は

$$
d W_{N}=h_{N} p L_{o} d x d y
$$

よつて図 1 のライダの摩耗量はこれらの総和として

$$
W=\iint h(x) p L_{o} d x d y
$$

仮定 4) によれば， $N$ 番目のライダさすべらせると き，ライダに戻る再転移量はそれまですべり面に蓄積さ れた転移路飞比例する。すなわち, ライダの長さ $x$ によ つて摩耗最つ減少する割合はそれまでの摩耗量に 1 次比 例するから次式が成立する。

$$
-\frac{d W}{d x}=k_{1} W
$$

式 (4), (5) か5 $h(x)$ の関数を求め, 初期条件 $x=$ 0 とおいて $h(x)=h_{0}$ であるとすると

$$
h(x)=h_{o} e^{-k_{1} x}
$$

よつて式（4）はつぎのようになる。

$$
W=h_{o} p L_{o} \iint e^{-k_{1} x} d x d y
$$

\section{1 ライダの形状による糜耗量の差異}

\section{1 .1 直方体ライダの摩耗量}

底面が長方形の角柱のライダを辺に平行にすべらせる 場合はライダの幅は一定であり, 式 (7)の $d y$ は積分 の外にはずせるから計算は簡単となる。積分のあとで初 期条件 $x=0$ に扮いて $W=0$ を入れ，ライダの寸法を 長さ $a_{1}$, 幅 $b_{1}$ と括けば直方体ライダの摩耗量 $W$ はつ ぎのようとなる。

$$
W=\frac{h_{o} p b_{1} L_{o}}{k_{1}}\left[1-e^{-k_{1} a_{1}}\right]
$$

図 2 は直方体ライダをすべらせたとき，分割した個々

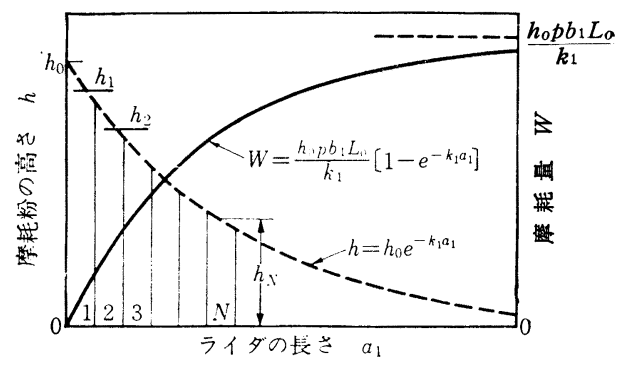

図 2 
のライダの摩耗粉の高さ $h$ の変化と, その積分であると ころの摩耗量の変化を図示したものである。

\section{1 .2 底面がひし形のライダの摩耗量}

ライダの底面が図 3 のようと，すべり方向の対角長が

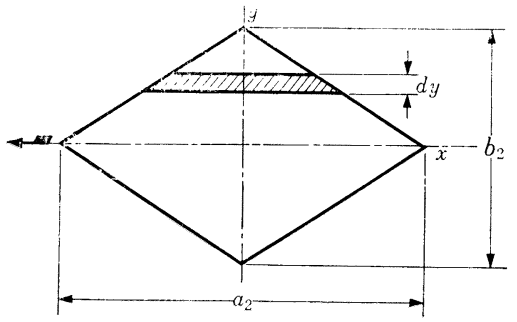

図 3

$a_{2}$, すべり方向と直角方向つ対角長が $b_{2}$ のひし形とす る。この場合 $x, y$ の関係恃上半分について考えるとつ ぎのようとなる。

$$
x=\frac{a_{2}}{b_{2}}\left(b_{2}-2 y\right)
$$

ひし形のライダの摩耗髽は上の関倸を式 (7) そ入れ， 2 倍して求める。

$$
\begin{aligned}
W & =\frac{2 h_{o} p L_{o}}{k_{1}} \int_{o}^{b_{2} / 2}\left[1-e^{-k_{1} \cdot a_{2} / b_{2} \cdot\left(b_{2}-2 y\right)}\right] d y \\
& =\frac{h_{o} D b_{2} L_{o}}{k_{1}}\left[1-\frac{1}{k_{1} a_{2}}\left(1-e^{-k_{1} a_{2}}\right)\right]
\end{aligned}
$$

2.1.3 円柱ライダの摩耗量

ひし形の場合と同様の考光で, 半径 $a_{3}$ の円柱ライダ をすべらせたときの摩耗量を求めると

$$
W=\frac{2 h_{o} p L_{o}}{k_{1}} \int_{o}^{a_{3}}\left[1-e^{-2 k_{1} \sqrt{a_{3}^{2}-y^{2}}}\right] d y
$$

あるいは

$$
\begin{gathered}
W=\frac{\sqrt{\pi} h_{o} p a_{3} L_{0}}{h_{1}} \sum_{N=1}^{\infty}\left(-2 k_{1} a_{3}\right)^{N} \\
\frac{N}{(N+1) !} \frac{\Gamma\left(\frac{N}{2}\right)}{\Gamma\left(\frac{N+1}{2}\right)}
\end{gathered}
$$

\section{2 ライダの形状効果}

2.2 .1 直方体ライダ同志の形状効果

底面が長方形の 2 辺の寸法比 $a_{1} / b_{1}$ を $n^{2}$ と㐨き，こ れと同面積の正方形の 1 辺を $a$ とすれば，この間には

$$
a_{1}=n a, \quad b_{1}=a / n
$$

両者のライダを拉なじ条件ですべらせ，その摩耗量の 比を形状効果 $\eta_{1}$ (正方形が長方形飞変わつたための効 果）と呼ぶことにする。雨者のライダ寸法を式(8) 飞人 れると, 形状効果 $\eta_{1}$ 致

\begin{tabular}{|c|c|c|c|}
\hline$n$ & {$\left[\gamma_{1}^{\prime}\right]_{k_{1} a=0}$} & {$\left[\eta_{1}{ }^{\prime \prime}\right] k_{1} a=0$} & {$\left[\eta_{1}{ }^{\prime \prime}\right]=0$} \\
\hline 4 & -1.5 & $21 / 6$ & 訟曲点なし \\
\hline 2 & -0.5 & $1 / 2$ & J \\
\hline $1 / 2$ & $1 / 4$ & 0 & "l \\
\hline $1 / 3$ & $1 / 3$ & $1 / 27$ & $k_{1} a_{1} \doteqdot 0.92$ \\
\hline $1 / 4$ & $3 / 8$ & $1 / 16$ & $k_{1} a_{1} \doteqdot 1.47$ \\
\hline
\end{tabular}

$$
\eta_{1}=\frac{1}{n} \frac{1-e^{-n k_{1} a}}{1-e^{-k_{1} a}}
$$

この曲線を図 4 亿示し, その性質を表 1 に揭げた。

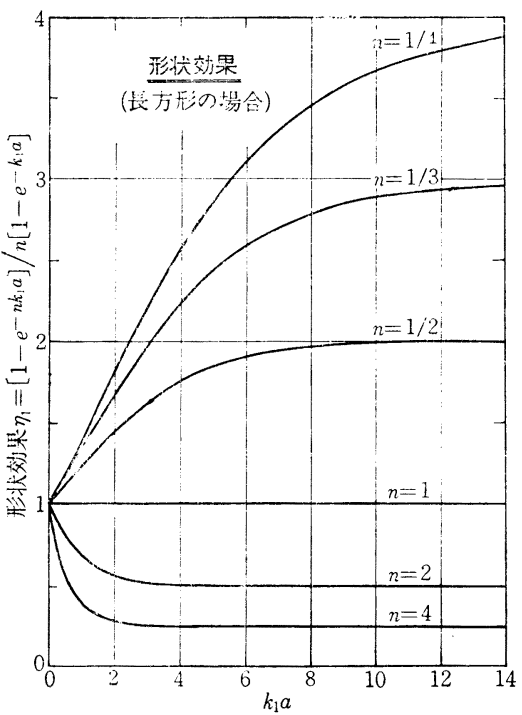

図 4 長方形ライダ同志の形状効果

表 $1 \quad \eta_{1}$ の性質

すなわち $k_{1} a$ の值仁よつて形状効果 $\eta_{1}$ は異なり, これ は末た寸法比 $n^{2}$ の值化も左右される。 $k_{1} a$ が非常に小 さいときは $\eta_{1} \doteqdot 1$ になるが， $k_{1} a$ がしだいに大きくな

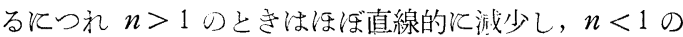
とき山潘線的に增加与る。さらに $k_{1} a$ の值が大きく なると $\eta_{1}$ は $1 / n$ の㙁に近づく。

2.2.2 底面がひし形のライダ同志の形状効果

底面がひし彩であり, その二つの対角長の比 $a_{2} / b_{2}$ が $n^{2}$ のライダを対角線方向にすべらせたときの摩耗量と， これと同面積で $n=1$ のひし形ライダをな゙ららたとき* の摩耗量の比を形状效果 $\eta_{2}$ とすれば，式（9）から

$$
\eta_{2}=\frac{1}{n} \frac{1-\frac{1}{n k_{1} a^{\prime}}\left(1-e^{-n k_{1} a^{\prime}}\right)}{1-\frac{1}{k_{1} a^{\prime}}\left(1-e^{-k_{1} a^{\prime}}\right)}
$$

*底面が正方形のライダを対角線方问にすべらせた ことになる。 
ここで $a^{\prime}$ は $n=1$ のひし形ライダの対角長である。 式 (12) の曲線を図 5 飞示し, その曲線の性質を表 2 飞 まとめたが，この曲線は図 4 の曲線と性質がよく似てい る。

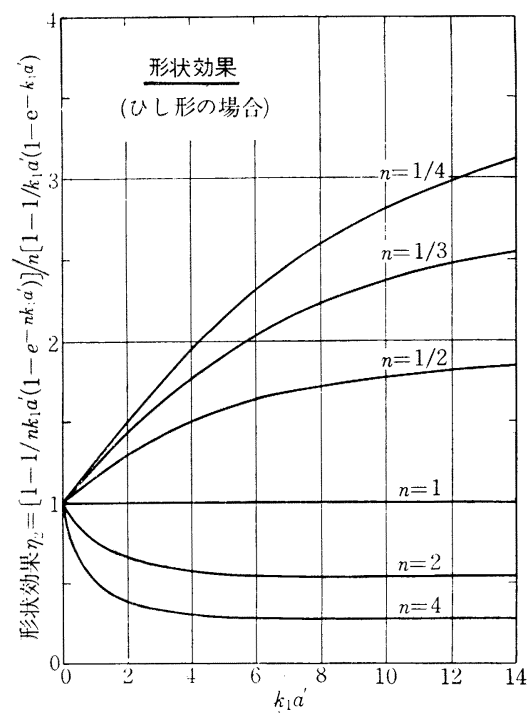

図 5 ひし形ライダ同志の形状効果

表 $2 \quad \eta_{2}$ の性質

\begin{tabular}{l|c|c|c}
\hline$n$ & {$\left[\eta_{2}{ }^{\prime}\right] k_{1} a^{\prime}=0$} & {$\left[\eta_{2}{ }^{\prime \prime}\right] k_{1} a^{\prime}=0$} & {$\left[\eta_{2}{ }^{\prime \prime}\right]=0$} \\
\hline 4 & -1 & $11 / 6$ & 変曲点なし \\
2 & $-1 / 3$ & $5 / 18$ & $J$ \\
$1 / 2$ & $1 / 6$ & $-1 / 27$ & $\prime \prime$ \\
$1 / 3$ & $2 / 9$ & 0 & $\prime \prime$ \\
$1 / 4$ & $1 / 4$ & $1 / 96$ & $k_{1} a^{\prime} \doteqdot 1.07$ \\
\hline
\end{tabular}

2.2.3 ライダの底面が $n=1$ のひし形の形状効果 底面が 1 辺 $a$ の正方形の角柱ライダを対角線方向にす べらせたときの摩耗最と，辺に平行にすべらせたときの 摩耗最の比を $n=1$ のひし形の形状効果 $\eta_{3}$ と定義すれ ば, 式 (8), (9) から

$$
\eta_{3}=\frac{\sqrt{2}-\frac{1}{k_{1} a}\left(1-e^{-\sqrt{2 k_{1} a}}\right)}{1-e^{-k_{1} a}}
$$

\subsection{4 円柱ライダの形状効果}

円柱ライダをすべらせたときの摩耗量と, 底面がこれ と同面積の 1 辺 $a$ の正方形の角柱ライダを辺に平行にす ベらせたときの摩耗量の比を形状効果 $\eta_{4}$ とすれば，式 (8), (10) 加

$$
\eta_{4}=\frac{2}{a\left[1-e^{-k_{1} a}\right]} \int_{0}^{a / \sqrt{\pi}}\left[1-e^{-2 k_{1} \sqrt{a^{2} / \pi-y^{2}}}\right] d y
$$

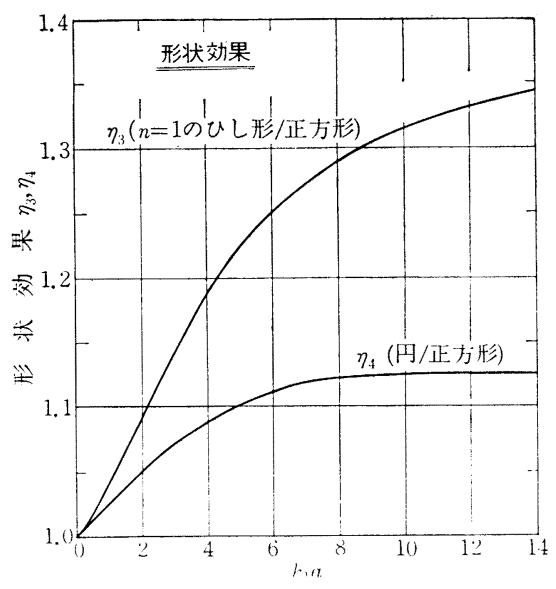

図 6 形状効果 $\eta_{3}, \eta_{4}$

表 $3 \quad \eta_{3}, \eta_{4}$ の性質

\begin{tabular}{c|c|c|c|c}
\hline 形 状 & {$\left[\eta_{3}{ }^{\prime}\right] k_{1} a=0$} & {$\left[\eta_{3}{ }^{\prime \prime}\right] k_{1} a=0$} & {$\left[\eta_{4}{ }^{\prime \prime}\right]=0$} & 旉近值 \\
\hline$n=1$ の & $(3-2 \sqrt{2}) / 6$ & $(3-2 \sqrt{2}) / 6$ & $k_{1} a \fallingdotseq 0.62$ & $\sqrt{2}$ \\
ひし形 & $(3-2 / \sqrt{2}$ \\
円 & - & - & - & $2 / \eta^{2}$ \\
\hline
\end{tabular}

図 6 は形状効果 $\eta_{3}, \eta_{4}$ を図示したものであり，それ らの性質を表 3 に揭げた。すなわち $k_{1} a$ の值が非常に小 さいときは $\eta_{3}, \eta_{4}$ はいずれも 1 亿近いが， $k_{1} a$ が大き くなるにつれ，それぞれ $\sqrt{2}, 2 / \sqrt{\pi}$ に漸近してゆ $<$ 。

以上は底面積が同一の場合飞, 底面が正方形の角柱ラ イダを標準として形状効果を考えてきた。同一底面積で 異なる形状をもつ場合の比較は類似の計算で求めること ができ，あるいはつぎにあげた例のように $\eta_{1}, \eta_{2}, \eta_{3}, \eta_{4}$ を組合わせて求めることもできる。

i) $\frac{\text { 長方形 } \mathrm{A}}{\text { 長方形 } \mathrm{B}}=\frac{\text { 長方形 } \mathrm{A} / \text { 正方形 }}{\text { 長方形 } \mathrm{B} / \text { 正方形 }}=\frac{\eta_{1}(\mathrm{~A})}{\eta_{1}(\mathrm{~B})}$

ii） $\frac{\text { ひし形 }}{\text { 正方形 }}=\frac{\text { ひし 形 }}{n=1 \text { のひし形 }} \cdot \frac{n=1 \text { のひし形 }}{\text { 正方形 }}$

$$
=\eta_{2} \cdot \eta_{3}
$$

\section{3 ライダの寸法効果}

図 1 の方法はライダを細分化することによつて摩耗量 を計算したものである。しかしながら，もともと1個の ライダは細分割しても分割した個々のライダ同志のあい だには上下方向の自由度がない。したがつてもとの 1 個 のライダをすべらせるとき，その摩耗深さは図2 亿示し たようにライダの長さによつて変化せず，医湾均一の摩 耗深さをとるであるう。この摩耗深さはライダの寸法に 
よつて桨化するので，つぎそその影響を調べることにす る。

2.3 .1 直方体ライダの寸法効果

底面が長さ $a_{1}$, 幅 $b_{1}$ の長方形のライダに圧力 $p$ を 加え, 辺に平行に $L_{0}$ だけすべらせ, ライダがほぼ一様 に $h_{1} p L$ 。の梁さに摩耗したと考えれば, その摩耗量は つぎのごとくおらわされる。

$$
W=h_{1} p a_{1} b_{1} L_{o}
$$

式 (8), (15) の摩耗量を等しいものと考光, 寸法効 果として $\zeta_{1}=\overline{h_{1}} / h_{0}$ を入れれば, 上式はつぎのように変 形される。

$$
W=h_{o} \zeta_{1} P L_{o}
$$

ここで $P$ は見掛けの荷重であり， $\boldsymbol{\zeta}_{1}$ はつぎの值をと ろ。

$$
\zeta_{1}=\frac{h_{1}}{h_{0}}=\frac{1-e^{-k_{1} a_{1}}}{k_{1} a_{1}}
$$

すなわち摩耗量はライダの長さを0まで極限させ，荷 重 $P$, 摩擦距離 $L_{0}$ のときの摩耗量飞寸法効果 $\zeta_{1}$ 老乗 ずることによつて求められる。よつてこのようならを寸 法効果と定義した。

この寸法効果 $\zeta_{1}$ はライダの幅 $b_{1}$ そ無関係であり, ライダの長き $a_{1}$ が長くなるとつれて減少する。また同 時にライダに再転移するときの常数 $k_{1}$ の值にも左右さ れ， $k_{1}$ は $a_{1}$ とおなじ効果を与える。

\subsection{2 底面がひし形の角柱ライダの寸法効果}

底面が対角長さ $a_{2}, b_{2}$ のひし形のライダをすべらす とき, その摩耗量はつぎのごとくあらわされよう。

$$
W=h_{2} p \cdot \frac{1}{2} a_{2} b_{2} \cdot L_{o}
$$

式 (9), (17) の摩耗量を等しいものと考え, 寸法効果 として $\boldsymbol{\zeta}_{2}=h_{2} / h_{0}$ を入れて前と同様に解けば

$$
\begin{aligned}
& W=h_{o} \zeta_{2} P L_{o} \\
& \text { ここで } \\
& \boldsymbol{\zeta}_{2}=\frac{2\left[1-\frac{1}{k_{1} a_{2}}\left(1-e^{-k_{1} a_{2}}\right)\right]}{k_{1} a_{2}}
\end{aligned}
$$

\subsection{3 円柱ライダの寸法効果}

沶なじように, 半径 $a_{3}$ の円柱ライダの寸法効果 $\zeta_{3}$ を 求めれげ

$$
\boldsymbol{\zeta}_{3}=\frac{2 \int_{0}^{a_{3}}\left[1-e^{-2 k_{1} \sqrt{a^{2} 3^{-y^{2}}}}\right] d y}{\pi k_{1} a_{3}^{2}}
$$

またライダの底面積が等しい場合にのみ，これらの寸 法効果と形状効果のあいだとつぎの関係が成立する。

$$
\begin{aligned}
& \eta_{3}=\zeta_{2} / \zeta_{1} \\
& \eta_{4}=\zeta_{3} / \zeta_{1}
\end{aligned}
$$

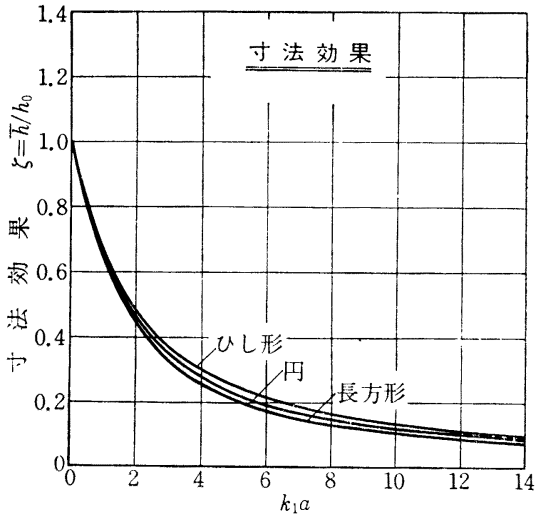

図 7 寸法効果 $\zeta_{1}, \zeta_{2}, \zeta_{3}$ の比較

これらの寸法効果を比較するには同一底面積のもとで 括こなう必要があるう。それゆえ寸法効果を比較した図 7 では横軸に 1 辺 $a$ の正方形を基準にとり, 縌軸にはこ れと同面積の長方形, ひし形, 円などの柱状ライダの寸 法効果 $\zeta_{1}, \zeta_{2}, \zeta_{3}$ をとつた。

図 7 の曲線からつぎのことがい方る。

1) これらの寸法効果はライダの長さに対して指数関 数的に減少与る。

2）ライダの底面䅡がおなじ場合に，寸法効果の值を 大きい順から並べれば，さし形，円，長方形となるが， これらの值は大差がなく, ライダの長さによる影響を大 きく受ける。

3） $k_{1} a$ の值が非常に小さいときは $\zeta \fallingdotseq 1$ ，すなわち ライダの形状効果, 寸法効果があらわれない。

4) 表 4 と示したように $k_{1} a=1.0$ まではそれぞれ の寸法効果の值はほとんど等しい。それゆ党 $k_{1} a$ がこの

表 4 寸法効果 $\zeta$ の比較

\begin{tabular}{c|c|c|c}
\hline$k_{1} a$ & $\zeta_{1}$ & $\zeta_{2}$ & $\zeta_{3}$ \\
\hline 0.5 & 0.787 & 0.801 & 0.799 \\
1.0 & 0.632 & 0.657 & 0.650 \\
\hline
\end{tabular}

程度までであれば式（17），(18）のかわりに式（16）を 代用してもよい。

\section{3. 実験方法}

図 1 の細分割した個々のライダの摩耗量を実験的に求 めるために図 8 の装置を使用した。すなわち, 図 1 の模 型で細分割したライダを $N$ 番目まですべらせた摩耗量 はこの装置で $N$ 回繰り返しこすつた時の摩耗減等し w。 


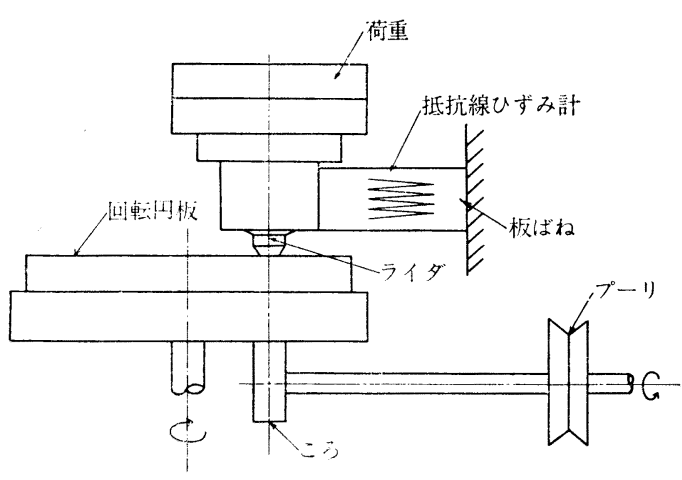

図 8 摩耗実娩装置

図8の装置に和いて, 試料のライダは板ばねの先端に チャックさ礼，荷重はライダ直上の括昆りとよつて加兑 る。動力はVプーリと同軸の「ころ」を介して回転円 板伀㒓される。摩擦速度はできるだけ技そくし（10 $\mathrm{mm} / \mathrm{s}$ ), 摩擦熱の発生を防いだ。

ライダは $4 \mathrm{~mm} \phi$ あるいは $4.5 \mathrm{~mm} \phi$ の円柱汇加 エし, その端面は\#06エメリ紙で均一に仕上げた。 その材質に㳻性質のあきらかである $\mathrm{Au}, \mathrm{Cu}, \mathrm{Cd}$ などの軟質純金属を選んだ。

回転円板古直径 $220 \mathrm{~mm}$ つ炭素鋼 S $15 \mathrm{C}$ を使用 した。円板表面はあらかじめ研削によつて $H_{\max }$ $0.8 \mu$ 程度の良好な平坦度のものをこしら兄て扮き， この面を\#280 の歪石でラップし，表面あらさが $H_{\max } 3.7 \mu$ 前後の注济一様な平面汇仕上げた。

これらの試料, 回転円板は材質に適した脱脂, 洗 浄を抏こなつたあとで実験使用した。

\section{4. 実 験 結果}

\section{1 摩耗粉の再転移}

摩耗粉が再転移することを実験的汇確かめた一つ を図9に示した。仮定 1) の摩耗粉が酸化しない条 件を保つためにライダに Au を選えだ。実験の観察 とよれば仮定 2)の $\mathrm{Cu}$ の摩耗粉の飛び散りがほと んど見られなかつた。実験結果は類似の条件で 2 回 おこない同一傾向が現われたので信頼できょう。図 9 亿沶いて繰り返し数 $N=15$ までは図 2 と抢なじ 曲線を描くが，そのあとは摩耗量が一定值に近づか ず，直線的に増加した。回転円板をガラスとした追 加の実験ではこの直線的増加の部分がなく, 一定值 が得られだ。それゆえ途中から摩耗量の増加は S 15 Cの回転円板か酸化したものと考光られる。ともか く図9の実験では繰り返し数 $N=15$ までは転移と
再転移を考慮した式（8）のように摩耗は進行している。

摩耗粉の再転移を確認するための第 2 の実験が 図 10 である。材料の組合わせを $\mathrm{Cu} / \mathrm{S} 15 \mathrm{C}$ とした場合は途中ま で式(8)のようと摩耗は進行するから, 図2のような曲 線となる。しかしそのあと繰り返し数が増すと摩耗量は ゆるい勾配で増加し，その值は一定に近づかない。その 原因は仮定 1）拉よび 2) がくずれたものと思われる。

観察によれば事実 $N=10$ そ扮いてライダ端面にわず かではあるが酸化した条痕を発見した。したがつて摩耗 粉も酸化する可能性があり, もしこれが剝離してルーズ な摩耗粉となればライダには再転移しにくくなり, むし ろ埋没するであるう7)。またルーズな摩耗粉はラップ作 用をするからでライダをすりへらす。このような状態に なればライダ自身がラップ剤を作ることになり摩耗がさ らに促進されることになる。しかしながらルーズな摩耗 粉は飛散しやすく, ライダに作用する有効のラップ剂が

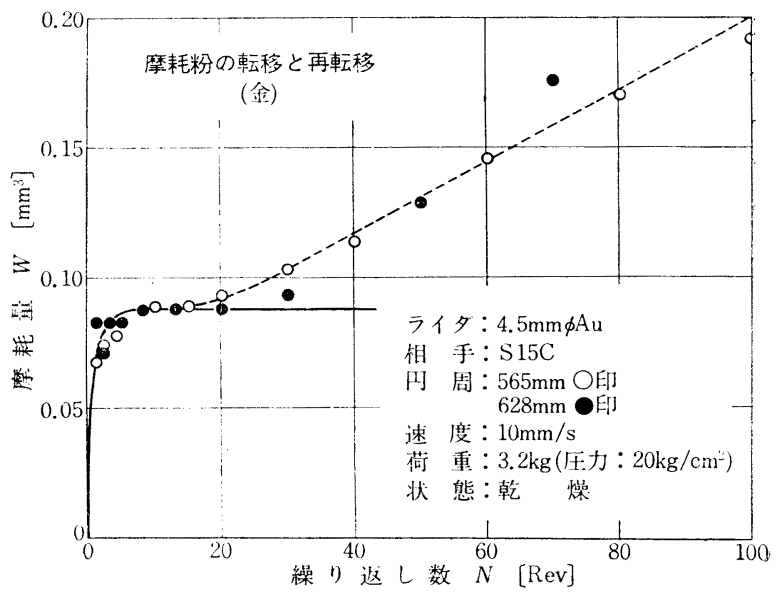

図 9 摩耗粉の転移と再転移（金）

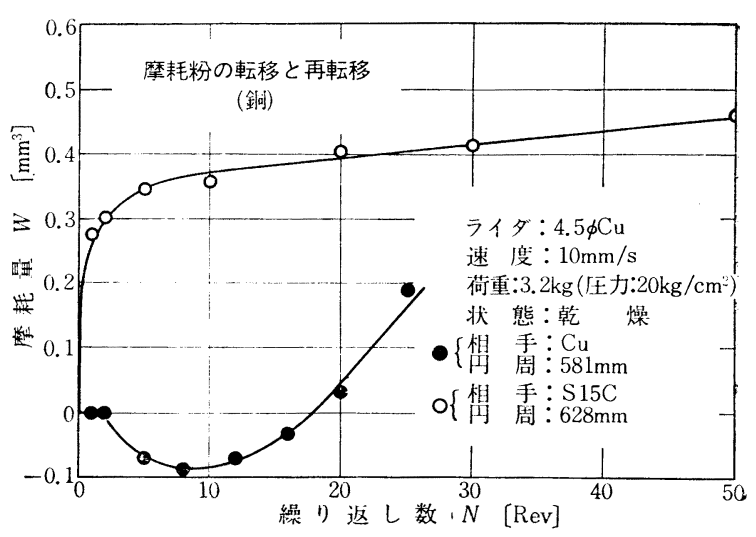

図 10 摩耗粉の転移と再転移（銅） 
常に一定であるとすれば, 摩耗量の直線的増加部分が説 明できる。ともかく仮定 1)，2）が実験終了まで成り立 つならば, 図 10 の $\mathrm{Cu} / \mathrm{S} 15 \mathrm{C}$ の組合わせ飞よる摩耗量 は $0.35 \mathrm{~mm}^{3}$ を越える值にならないであろう。

一方，材料の組合わせを $\mathrm{Cu} / \mathrm{Cu}$ とすると，図10の下 の曲線のようとなり，図2のような形にならない。この 曲線は $N=2$ まで摩耗量が0で, そのあと摩耗量は一 度負になつてから増加を始める。この摩耗量が負となつ た現象は回転円板の $\mathrm{Cu}$ がライダと転移したことであつ て，それ以外の理由は考光られない。このことは回転円 板に転移した摩耗粉の 1 部がライダに再転移することの 有力な証拠となる。

仮定 4) 飞従つて再転移量がそれまでの摩耗量飞比例 するならば， $\mathrm{Cu} / \mathrm{Cu}$ の組合わせのときは招互いと転 移, 再転移し合つて見掛けのライダの摩耗量は常飞 0 となるはずであるが，実験では繰り返し数 $N=2$ まで しかこのことがいえなかつた。しかしながら，この事 実は短い期間ではあるが仮定 4) が成り立つことを支 持する結果である。それは異種金属の組合わせの場合 はこの報告の全般にわたつて見られるごとく, 初めに かならず摩耗量が多いからである。

$N=2$ すぎて負の摩耗量があらわれた原因について は，回転円板の表面あらさがライダの表面あらさより も遙か飞荒いため飞凝着部のせん断破壞個所のほとん どが回転円板の内部で生じたものと解釈している。

実験の扔わりごろに見られる摩耗量の増加は摩耗粉 が脱落してトラックから飛び散つて抢り, またライダ

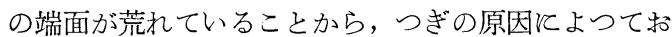
きたものと推測される。すなわち転移，再転移をはげし く行なつた摩耗粉は加工ひずみを受けて凝着能力が弱ま り脱落した摩耗粉となることが考光られる。このような 摩耗粉がライダに凝着する予定のものであれば，その重 量だけライダは摩耗したことになる。また餅のようなと の摩耗粉が接触面に凝着し, そのため表面あらさを悪く し，摩耗を促進させるかも知れない。

転移，再転移をたしかめるためとはライダのみでな く，円板の摩耗飞も注目しなければならないが，ライダ の挙動を十分飞観察しても再転移があることと，そのた め摩耗の進行が抑制されることを図9, 図10 の結果は 教えてくれる。

\section{2 常数 $k_{1}, h_{o}$ の決定}

繰り返し摩耗試験の初期では摩耗粉の酸化がされにく くまた摩耗粉がトラックから飛び散ることも少ないこ とが観察されたので，この期間で常数 $k_{1}$ と $h_{0}$ を求め るのが得策である。この期間では式 (10) が成立する
が， $k_{1} a$ の值が小さいので近似的に式(8) を使用する社 うが便利である。

常数 $k_{1}, h_{o}$ を求めるため式(8) をつぎのようと変形 する。

$$
\log \left(1-\frac{W}{p a L_{o}} \frac{k_{1}}{h_{o}}\right)=-\frac{k_{1} N}{2.3026} a
$$

ここで $a$ はライダの底面を正方形と考えたときの 1 辺 の長さである。上式で $a, p, L_{o}$ は実験条件として与兄 られ, 摩耗量 $W$ 以実験結果として得られる。それゆえ 上式を片対数ととり，実験值をプロットすれば，その直 線の勾配として $k_{1}$ が求められ，付随して $h_{0}$ も求ま る。

図 11 は Cd/S15C を組合わせたときのCd ライダの

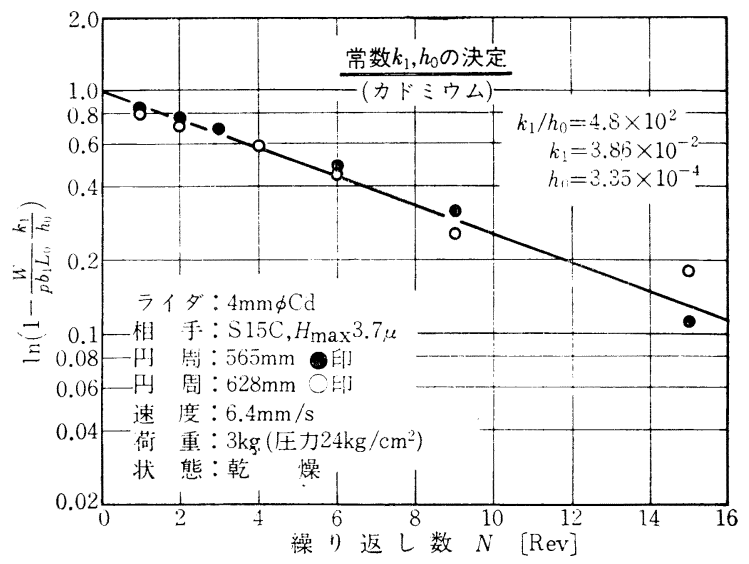

図 11 常数 $k_{1}, h_{0}$ の決定（カドミウム）

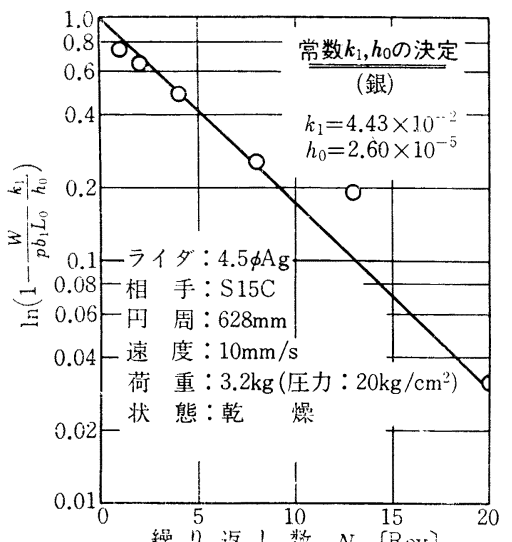

繰り返し粼 $N$ [Rev]

図 12 常数 $k_{1}, h_{0}$ の決定 (銀)

摩耗を調べ，図 12 は $\mathrm{Ag} / \mathrm{S} 15 \mathrm{C}$ を組合わせたときの $\mathrm{Ag}$ ライダの摩耗を調べたものであり，いずれもよい直 線性を示し，仮定 4)の1次比例の仮定が実験的汇よく 
一致したことをあらわしている。これらの罒から求めた 常数 $k_{1}, h_{0}$ の值をつぎに示す。

i) Cd ライダの場合

$$
\begin{aligned}
& k_{1}=3.86 \times 10^{-2}\left(\mathrm{~mm}^{-1}\right) \\
& h_{0}=3.35 \times 10^{-4}\left(\mathrm{~mm}^{2} / \mathrm{kg}\right)
\end{aligned}
$$

ii) $\mathrm{Ag}$ ライダの場合

$$
\begin{aligned}
& k_{1}=4.43 \times 10^{-2}\left(\mathrm{~mm}^{-1}\right) \\
& h_{o}=2.60 \times 10^{-5}\left(\mathrm{~mm}^{2} / \mathrm{kg}\right)
\end{aligned}
$$

さきに示した図9, 図100実験からは

iii) Au ライダの場合

$$
\begin{aligned}
& k_{1}=1.92 \times 10^{-1}\left(\mathrm{~mm}^{-1}\right) \\
& h_{o}=3.78 \times 10^{-5}\left(\mathrm{~mm}^{2} / \mathrm{kg}\right)
\end{aligned}
$$

iv) $\mathrm{Cu}$ ライダの場合

$$
\begin{aligned}
& k_{1}=2.68 \times 10^{-1}\left(\mathrm{~mm}^{-1}\right) \\
& h_{o}=1.86 \times 10^{-4}\left(\mathrm{~mm}^{2} / \mathrm{kg}\right)
\end{aligned}
$$

\section{5. 検 討}

\section{1 再転移に対する検討}

1956 年に等者ら ${ }^{8)}$ は摩耗粉の凝着と蓄積が摩耗現象に 大きな役割堂はたしていることを報告した。その後 Archard $\left.^{9}\right)$ はラジオ・アイソトープを使用して摩耗粉がラ イダに再転移することを確認し，その挙動について観察 を扣こなつた。しかし転移量, 再転移量について定量的 な解析をおこなうまでに恎らなかつた。

この報告では再転移の確認はいろいるな材質組合わせ の結果から得ている。

\section{2 常数 $k_{1}, \boldsymbol{h}_{0}$ に対する検討}

転移量 $h_{0}$ は筆者が従来より提唱してきた比摩耗量 ${ }^{10)}$ の考えを一歩前進させた。すなわち比摩耗量 $W_{s}$ はこの 報告のなかひ $\bar{h}$ とまつたく同じものであつて，そのなか には形状効果, 寸法効果が含まれている。このことは試 験方法によつて，その值が変わり得ることを意味する。 しかし繰り返しのない摩耗実験では，この報告で求めら れた $k_{1}$ の值が非常に小さいため, またライダの寸法が 小さいため形状効果や寸法効果が明瞭にあらわれず，過 去の実験では見落されていた。これらの効果は実験室的 試験結果を現実問題の解決に利用するとき，たとえば試 料が実験的には小で現実には大である場合などのとき， はつきりと確認されるであるう。

常数 $k_{1}, h_{0}$ の值はライダ, 回転円板, 摩耗粉のどれか が酸化す机ば変化するものと思われる。とれゆえ，もし 金属表面から完全によごれを取り去るならば，これらの 值は実験で求めた值よりも上回るものと予測される。ま た相手材質によつて, あるいは表面あらさによつて常数 $h_{o}$ が変化するのが追加の実験で判明した。よつて摩耗粉 の転移, 再転移について定量的な解決を与えるために は，さらに 2 物体間に働く表面エネルギの問題や摩耗粉 の発生機構などを調べる必要があろう。

\section{6. 結 論}

以上述べてきたことを要約するとつぎのことがいえ る。

i ) 非潤滑状態に括ける繰り返しのない摩耗では仮定 1)，2），3），4）が成立することが予期される。

ii）試料の寸法が長さ $x$, 幅 $y$ のライダに接触圧力 $p$ を加え， $L_{0}$ すべらせたときの摩耗量は次式で与えられ る。

$$
\begin{gathered}
W=h_{o} p L_{o} \iint e-k_{1} x d x d y \\
\text { ただし } k_{1}, h_{o} ; \text { 常数 }
\end{gathered}
$$

iii）試料が小さい場合には形状効果と寸法効果を考慮 する必要がない。

iv）試料が大きな場合には形状効果 $\eta$ ，あるいは寸法 効果 $\zeta$ を補正係数として乗ずる必要がある。

v) 摩耗粉の転移, 再転移を確認し, 実験より常数 $k_{1}$, $h_{0}$ の值を求めた。

抒わり飞本研究は昭和 37 年度生産加工技術の研究補助 金の一部によつて行なつたもので，御指導を仰いだ大越 諒先生，ならびに実験に協力していただいた横溝武君， 久保田清志君, 粕田量彦君に感謝するとともに, 助言を 頂いた中央検定所の山本健太郎博士，当研究室の諸氏に 厚く括礼をのべます。（1962年10月3日 受付）

\section{交献}

1) 水野万亀雄: 精密機栈, 27巻 (1961) 426 .

2) 水野厅亀雄: 精密機械, 28巻 (1962) 12 .

3) R. Holm : Symposium on Electric Contact (1953).

4) B. W. Sakmann \& J. T.Burwell ; J. Appl. Phys. Vol. 15 (1944) 459.

5) E. Rabinowicz : Proc. of Phy. Soc., B, Vol. 66 (1953) 929.

6) 佐田登志夫 : 精密機械, 25巻 (1959) 275 .

7) 水野万龟雄: 精密機械, 26巻 (1960) 657 .

8) 大越諒, 佐田登志夫, 水野万亀雄, 鴨川昭夫 : 昭和 30 年度試験研究委託事業費による研究報告 書 (1956) 92.

9) J.F. Archard \& W. Hirst : Proc. Roy. Soc., A. Vol. 238 (1957) 515

10) 大越諒, 佐田登志夫, 水野万亀夫 : 科研報告, Vol. 31 (1955) 103. 